\title{
Właściwości poliamidu PA 12 w aspekcie warunków technicznych projektowania, budowy i eksploatacji gazociągów o MOP 1,6 MPa
}

\section{PA12 polyamide properties in the aspect of technical conditions for design, construction and operation of gas pipelines with MOP 1.6 MPa}

\author{
Piotr Szewczyk \\ Instytut Nafty i Gazu - Państwowy Instytut Badawczy
}

\begin{abstract}
STRESZCZENIE: Zasadniczą zaletą poliamidu PA 12 jest możliwość jego stosowania do budowy gazociągów o MOP = 1,6 MPa, tj. w zakresie ciśnień, dla którego w Polsce gazociągi budowane są wyłącznie z rur stalowych. Budowa gazociągów z materiałów innych niż stal i polietylen nie jest w Polsce możliwa ze względu na ograniczenia prawne (Rozporządzenie Ministra Gospodarki z dnia 26 kwietnia 2013 r. w sprawie warunków technicznych, jakim powinny odpowiadać sieci gazowe i ich usytuowanie). Obecnie trwają prace nad nowelizacją tego rozporządzenia, które między innymi mają umożliwić dopuszczenie do stosowania innych materiałów i technologii wykorzystywanych w Europie i na świecie. Do zapewnienia bezpiecznej budowy i eksploatacji sieci gazowych z nowych materiałów sama zmiana w przepisach nie jest jednak wystarczająca. W artykule opisano wybrane właściwości poliamidu PA 12 i powiązane z nimi warunki projektowania, budowy i eksploatacji gazociągów. Przedstawiono podstawowe kryteria wyznaczania maksymalnego ciśnienia roboczego, uwzględniające wytrzymałość długoczasową oraz zjawisko szybkiej propagacji pęknięć. Opisano zjawisko powolnej propagacji pęknięć oraz sposób sprawdzania odporności rur z PA 12 na jego wystąpienie, jak i wynikające z niego dopuszczalne uszkodzenia powierzchni rur. Przedstawiono warunki, jakie należy brać pod uwagę podczas transportu i składowania, uwzględniając odporność rur z PA 12 na promieniowanie UV. Ze względu na posiadaną właściwość, jaką jest elastyczność rur, opisano warunki zmiany kierunku gazociągu bez stosowania dodatkowych kształtek kątowych. Wskazano na możliwość zamykania przepływu gazu metodą zaciskania oraz zwrócono uwagę na konieczność zachowania większej ostrożności podczas prac eksploatacyjnych w temperaturach ujemnych ze względu na spadek elastyczności rur. Przedstawiono podstawowe parametry procesu zgrzewania doczołowego, które różnią się od tych stosowanych przy łączeniu rur i kształtek z PE. Zwrócono uwagę na konieczność modyfikacji parametrów dostępnych procedur prowadzenia prób szczelności wynikającą z większej sztywności obwodowej rur PA 12 niż PE.
\end{abstract}

Słowa kluczowe: gazociąg, właściwości poliamidu PA 12, wytrzymałość długoczasowa, maksymalne ciśnienie robocze, powolna propagacja pęknięć, zaciskanie, parametry zgrzewania, próba szczelności

ABSTRACT: The main advantage of PA12 polyamide is that it can be used in the construction of gas pipelines with MOP $=1.6 \mathrm{MPa}$, i.e. in the pressure range where in Poland gas pipelines are built exclusively from steel pipes. Construction of gas pipelines from materials other than steel and polyethylene is not possible in Poland due to legal restrictions (Regulation of the Minister of Economy of 26 April 2013 on technical conditions to be met by gas networks and their location). Currently, work is underway on the amendment of this regulation, which among others, is to allow for the use of other materials and technologies used in Europe and in the world. However, the legislative amendment alone is not sufficient to ensure the safe construction and operation of gas networks from new materials. The article presents selected properties of PA12 polyamide and associated conditions for the design, construction and operation of gas pipelines. The basic criteria for determining the maximum operating pressure including long-term resistance and the phenomenon of rapid crack propagation are presented. The phenomenon of slow crack growth and the method of testing the resistance of PA12 pipes to its occurrence as well as the resulting acceptable damages to pipe surfaces are described. The article presents the conditions to be considered during transport and storage taking into account the resistance of PA12 pipes to UV radiation. Due to the flexibility of pipes, the conditions for changing the direction of the gas pipeline without the use of additional angle fittings were described. The possibility of closing the gas flow by the clamping method was pointed out and attention was paid to the necessity of greater caution during operating works at negative temperatures due to a decrease in the flexibility of the pipes. The basic parameters of the butt welding process were presented, which differ from those used when connecting PE pipes and fittings. Attention was paid to the necessity to modify the parameters of available procedures for conducting leak tests due to higher circumferential stiffness of PA12 pipes compared to PE ones.

Key words: gas pipeline, polyamide PA12 properties, long-term resistance, maximum operating pressure, slow crack growth, squeezeoff, welding parameters, leak test.

Autor do korespondencji: P. Szewczyk, e-mail: piotr.szewczyk@inig.pl

Artykuł nadesłano do Redakcji 13.06.2019 r. Zatwierdzony do druku 24.10.2019 r. 


\section{Wprowadzenie}

Systemy rurowe $\mathrm{z}$ poliamidu PA 12 umożliwiają budowę gazociągów o maksymalnym ciśnieniu roboczym (MOP) 1,6 MPa. Poliamid, podobnie jak polietylen, jest polimerem należącym do grupy tworzyw termoplastycznych, który w podwyższonej temperaturze przechodzi w stan plastyczny i może być odpowiednio kształtowany, a po schłodzeniu twardnieje i odzyskuje właściwości pierwotne (Politechnika Wrocławska). Ze względu na uprządkowanie struktury wewnętrznej poliamid zaliczany jest do tworzyw krystalicznych (rys. 1).

Poliamid i polietylen posiadają wiele cech wspólnych, np. elastyczność, odporność na ścieranie, niskie współczynniki tarcia i przewodzenia ciepła, wysokie współczynniki odkształceń termicznych (Plastem - P. Ciupa i T. Teodorczyk). Materiały te w odniesieniu do niektórych właściwości różnią się jednak od siebie. Podstawową różnicą między poliamidem PA 12 a powszechnie stosowanym do budowy gazociągów do $\mathrm{MOP}=1,0 \mathrm{MPa}$ polietylenem PE 100 jest większa wytrzymałość poliamidu na ciśnienie wewnętrzne. Ponadto materiały te różnią się np. wartością modułu Younga i związaną z nim sztywnością obwodową, wartościami wydłużenia względnego do granicy plastyczności, temperaturami topnienia czy też chłonnością wody.

W obszarze, gdzie występują podobne cechy rur z PA 12 i z PE 100, przy określaniu warunków technicznych projektowania, budowy i eksploatacji gazociągów z poliamidu można stosować takie same wymagania jak w stosunku do gazociągów z polietylenu. Tam, gdzie występują zasadnicze różnice, dla zapewnienia bezpiecznej

\section{Polimery}

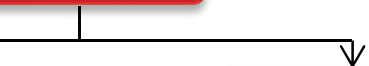

astomery

\section{$\checkmark$}

Termoplasty

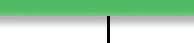

$\vee$

Amorficzne

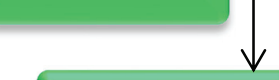

Krystaliczne $\vee$

Termoutwardzalne

Duroplasty

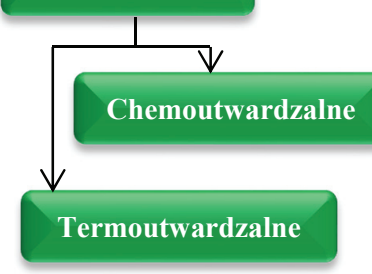

Rys. 1. Technologiczna klasyfikacja polimerów

Fig. 1. Technological classification of polymers

eksploatacji gazociągów już na etapie projektowania konieczne jest odmienne podejście.

\section{Wymagane właściwości PA 12 stosowanego w systemach do przesyłania gazu}

Wymagane właściwości materiału, rur i kształtek opisane są odpowiednio w normach ISO 16486-1:2012, ISO 164862:2012, ISO 16486-3:2012. Wybrane właściwości przedstawiono w tabelach 1 i 2 .

Tabela 1. Wybrane właściwości materiału PA $12 \mathrm{w}$ postaci granulatu

Table 1. Selected properties of PA12 compound in the form of granules

\begin{tabular}{|l|c|c|}
\hline \multicolumn{1}{|c|}{ Wlaściwość } & Wymaganie & Metoda badania \\
\hline \hline Gęstość & $1000-1040 \mathrm{~kg} / \mathrm{m}^{3}$ & $\begin{array}{r}\text { ISO } 1183-1 \\
\text { ISO } 1183-2\end{array}$ \\
\hline Wskaźnik lepkości & $\geq 180 \mathrm{ml} / \mathrm{g}$ & ISO 307 \\
\hline Zawartość wody & $0,10 \%$ & ISO 15512, Metoda B \\
\hline
\end{tabular}

Tabela 2. Wymagane właściwości materiału PA $12 \mathrm{w}$ postaci rur

Table 2. Required properties of PA12 compound in the form of pipes

\begin{tabular}{|l|c|c|}
\hline \multicolumn{1}{|c|}{ Wlaściwość } & Wymaganie & $\begin{array}{c}\text { Metoda } \\
\text { badania }\end{array}$ \\
\hline \hline Odporność na starzenie: & $\begin{array}{c}\text { próbki poddawane starzeniu } \geq 3,5 \mathrm{GJ} / \mathrm{m}^{2} \\
\text { powinny mieć właściwości podane poniżej: }\end{array}$ & $\begin{array}{c}\text { ISO } 16871 \\
\text { ISO 6259-1, } \\
\text { ISO 6259-3 } \\
\text { a }\end{array}$ \\
\hline a) Wydłużenie przy zerwaniu & & $\begin{array}{l}\text { ISO } 527-1, \\
\text { ISO } 527-2^{\mathrm{b}}\end{array}$ \\
\hline b) Wytrzymałość hydrostatyczna w $80^{\circ} \mathrm{C}$ & $160 \%$ & $\begin{array}{c}\text { ISO } 1167-1, \\
\text { ISO } 1167-2\end{array}$ \\
\hline c) Kohezyjna odporność połączenia elektrooporowego & brak uszkodzenia podczas badania przez 165 h & ISO 13954 \\
\hline
\end{tabular}


cd. Tabela $2 /$ ect. Table 2

\begin{tabular}{|c|c|c|}
\hline Właściwość & Wymaganie & $\begin{array}{l}\text { Metoda } \\
\text { badania }\end{array}$ \\
\hline $\begin{array}{l}\text { Wytrzymałość na szybką propagację pęknięć (test w pełnej skali) } \\
\left.\text { (ciśnienie krytyczne, } p_{c}\right)(e \geq 5 \mathrm{~mm})\end{array}$ & $\mathrm{p}_{\mathrm{c}} \geq 1,5 \mathrm{MOP}$ & ISO $13478^{\mathrm{e}}$ \\
\hline $\begin{array}{l}\text { Wytrzymałość na szybką propagację pęknięć } 0^{\circ} \mathrm{C} \text { (test S4) } \\
\text { (ciśnienie krytyczne, } \mathrm{p}_{\mathrm{c}, \mathrm{S} 4} \text { ) }\end{array}$ & $\begin{array}{l}\text { wartość } \mathrm{p}_{\mathrm{c}, \mathrm{S} 4} \text { określona } \mathrm{w} \text { tym badaniu jest wartością } \\
\text { odniesienia, } \mathrm{p}_{\mathrm{c}, \mathrm{S} 4 \mathrm{REF}} \text {, przywołaną } \mathrm{w} \text { wymaganiu testu } \\
\text { S4 określonym w ISO 16486-2:2012 }\end{array}$ & ISO 13477 \\
\hline Skurcz wzdłużny & $\leq 3 \%$ & ISO 2505 \\
\hline $\begin{array}{l}\text { Wytrzymałość na powolny wzrost pęknięć dla } e>5 \mathrm{~mm} \\
\text { (test z karbem) }\end{array}$ & brak uszkodzeń podczas badania przez $500 \mathrm{~h}$ & ISO 13479 \\
\hline Wytrzymałość przy próbie łamania Charpy & $\mathrm{a}_{\mathrm{cN}} \geq 10 \mathrm{~kJ} / \mathrm{m}^{2}$ & ISO $179-1 / 1 \mathrm{eA}$ \\
\hline
\end{tabular}

\section{Projektowanie}

Podstawowym wymaganiem stosowanym podczas projektowania gazociągów z poliamidu jest określenie warunków bezpiecznej eksploatacji w zakładanym okresie użytkowania, który wynosi minimum 50 lat. Na etapie projektowania podstawowym czynnikiem wpływającym na trwałość gazociągu jest dobór maksymalnego ciśnienia roboczego (MOP) z uwzględnieniem przewidywanej maksymalnej temperatury gazociągu. Poliamid należy do materiałów lepkosprężystych, co oznacza, że wykonane z niego rury po obciążeniu ciśnieniem wewnętrznym będą podlegały tzw. pełzaniu. Wielkość odkształcenia spowodowanego pełzaniem materiału będzie zależała od wielkości naprężenia pochodzącego od ciśnienia wewnętrznego, czasu obciążenia i temperatury. Uwzględnienie temperatury jest istotne, gdyż pełzanie będzie wzrastać dla takiego samego naprężenia i czasu obciążenia wraz ze wzrostem temperatury (Janson i Molin). Aby w wyniku pełzania materiału nie wystąpiło pęknięcie rury, wymagane jest określenie dopuszczalnego poziomu naprężeń dla zakładanego czasu użytkowania w określonej temperaturze, czyli wyznaczenie tzw. wytrzymałości długoczasowej, której miarą jest minimalna żądana wytrzymałość (MRS). Wykorzystując $M R S$ [MPa], wymiary geometryczne rury ( $S D R$ - szereg wymiarowy), współczynnik projektowy $C$ uwzględniający warunki eksploatacji i właściwości elementów systemu rurowego oraz współczynnik $D_{F}$ zależny od temperatury roboczej, maksymalne ciśnienie robocze wyznacza się ze wzoru:

$$
M O P=\frac{20 M R S}{C(S D R-1) D_{F}}[\mathrm{MPa}]
$$

Zgodnie z ISO 16486-1:2012 minimalna żądana wytrzymałość $M R S$ zależna jest od rodzaju poliamidu, którego wartości przedstawiono w tabeli 3. Wartości współczynnika uwzględniającego temperaturę zamieszczono w tabeli 4.

Wobec powyższego dla gazociągów z poliamidu PA 12 przewidzianych do użytkowania w okresie 50 lat, pracujących
Tabela 3. Minimalna żądana wytrzymałość rur z PA

Table 3. Minimum required strength of PA pipes

\begin{tabular}{|c|c|}
\hline $\begin{array}{c}\text { MRS } \\
{[\mathrm{MPa}]}\end{array}$ & Oznaczenie tworzywa \\
\hline \multirow{2}{*}{16} & PA-U 11160 \\
& PA-U 12160 \\
\hline \multirow{2}{*}{18} & PA-U 11180 \\
& PA-U 12180 \\
\hline
\end{tabular}

Tabela 4. Temperaturowe współczynniki obniżające

Table 4. Temperature derating coefficients

\begin{tabular}{|c|c|}
\hline $\begin{array}{c}\text { Temperatura } \\
{\left[{ }^{\circ} \mathbf{C}\right]}\end{array}$ & Wspólczynnik $\boldsymbol{D}_{\boldsymbol{F}}$ \\
\hline 20 & 1,0 \\
\hline 30 & 1,1 \\
\hline 40 & 1,25 \\
\hline
\end{tabular}

w temperaturze nie większej niż $20^{\circ} \mathrm{C}$ i wykonanych z rur SDR 11, przy zastosowaniu współczynnika projektowego $C=2$, maksymalne ciśnienie robocze wyniesie:

- $\mathrm{MOP}=$ 1,6 MPa dla PA-U 12 160;

- $\mathrm{MOP}=1,8 \mathrm{MPa}$ dla PA-U 12180.

Kolejną właściwością rur z PA 12 wykorzystywaną przy obliczaniu MOP jest odporność na szybką propagację pęknięć. Maksymalne ciśnienie robocze uwzględniające ciśnienie krytyczne szybkiej propagacji pęknięć $\left(p_{c}\right)$ obliczane jest według zależności:

$$
M O P=\frac{p_{c}}{1,5}
$$

Oznacza to, że dla rur z PA 12 przeznaczonych do przesyłania gazu wyznaczone na podstawie badań ciśnienie krytyczne $p_{c}$ powinno być nie mniejsze niż 2,4 MPa, przy czym ciśnienie krytyczne $p_{c}$ powinno zostać wyznaczone dla przewidywanej minimalnej temperatury roboczej. Ciśnienie krytyczne szybkiej propagacji pęknięć wyznaczone w temperaturze $0^{\circ} \mathrm{C}$ wynosi 3,0 MPa (Evonik Resource Efficiency GmbH, 2018), 
co potwierdza spełnienie powyższego kryterium. Ciśnienie krytyczne $p_{c}$ może być wyznaczone zarówno za pomocą testu w pełnej skali, jak i testu S4, które szczegółowo opisane zostały w publikacji A. Wróblewskiej (2013).

\section{Budowa i eksploatacja}

Ze względu na ograniczoną odporność na uszkodzenia mechaniczne wyroby z PA 12 mogą ulegać uszkodzeniom, np. w postaci zarysowania ich powierzchni. Uszkodzenia te mogą inicjować zjawisko tzw. powolnej propagacji pęknięć. Pod powstałym defektem będzie wytwarzała się strefa uplastycznionego materiału, gdzie będzie dochodziło do przemieszczeń łańcuchów polimeru i powstawania porów. Wraz z upływem czasu pory te będą się powiększały i będzie dochodziło do pękania włókien prostopadłych do kierunku propagacji pęknięcia. W efekcie dno uszkodzenia będzie przemieszczało się w głąb ścianki rury, co ostatecznie doprowadzi do jej pęknięcia (Szewczyk, 2012). To, w jakim stopniu rury z PA 12 są odporne na powolną propagację pęknięć, jest określane na podstawie badań wg normy PN-EN ISO 13479:2013. Podczas badania zgodnie z parametrami według ISO 16486-2:2012 rury z naciętymi na ich powierzchni karbami o głębokości $20 \%$ grubości ścianki nie powinny ulec uszkodzeniu podczas badania wytrzymałości hydrostatycznej w czasie $500 \mathrm{~h}$. W rzeczywistych warunkach eksploatacji przyjmuje się, że rury nie powinny zawierać uszkodzeń większych niż 10\% grubości ścianki. Dlatego też rury powinny być składowane i transportowane na powierzchniach płaskich wolnych od kamieni i innych występów lub ostrych przedmiotów. Wymaganie to ma również zastosowanie podczas układania rur w gruncie, gdzie jednym ze sposobów zabezpieczenia przed uszkodzeniami mechanicznymi jest wykorzystanie podsypki i obsypki piaskowej. Zastosowanie gruntu rodzimego jest dopuszczalne pod warunkiem, że jest on wolny od kamieni i ostrych przedmiotów mogących uszkodzić rurę (ISO 16486-6:2012).

Jak deklaruje producent surowca PA 12 (Evonik Resource Efficiency GmbH, 2018), rury z niego wyprodukowane są odporne na obciążenia punktowe, co umożliwia ich instalowanie w gruncie rodzimym zawierającym stałe elementy, np. kamienie. Przed budową gazociągu w takich warunkach niezbędne będzie jednak potwierdzenie tej właściwości dla rur wyprodukowanych przez danego producenta.

Rury z PA 12 są podatne na różnego rodzaju odkształcenia. Jednymi z nich są odkształcenia w przekroju poprzecznym, które mogą powstać podczas niewłaściwego składowania. Zbyt duży nacisk górnych warstw rur składowanych w odcinkach prostych jedna na drugiej będzie powodował nadmierną owalizację, która może negatywnie wpływać na jakość wykonywanych połączeń zgrzewanych. Dokładna wysokość, do której można układać proste rury, zależy od wielu czynników, takich jak materiał, rozmiar, grubość ścianki i temperatura otoczenia (ISO 16486-6:2012), dlatego należy w tym zakresie przestrzegać zaleceń producenta rur.

Rury z poliamidu PA 12, podobnie jak rury z polietylenu, posiadają ograniczoną odporność na promieniowanie UV, które nie może przekroczyć wartości 3,5 GJ $/ \mathrm{m}^{2}$. Dla Europy Centralnej przyjmuje się, że maksymalny okres składowania rur poddanych oddziaływaniu promieniowania UV nie powinien przekroczyć 1 roku (DVGW GW 335-A6(P):2015).

Pozytywną właściwością rur PA 12 jest ich elastyczność, umożliwiająca zwijanie produkowanych rur w kręgi lub nawijanie na bębny, dzięki czemu podczas budowy możliwe jest ograniczenie liczby połączeń. Elastyczność rur PA 12 może być również wykorzystywana do zmiany kierunku gazociągu bez stosowania dodatkowych kształtek kątowych. Należy jednak wówczas zachować minimalny promień gięcia $\geq 25 \times d$, gdzie $d$ oznacza średnicę zewnętrzną rury [mm]. Uzyskanie zmiany kierunku gazociągu z zastosowaniem mniejszych promieni gięcia jest dopuszczalne pod warunkiem, że jest to zgodne $z$ doświadczeniem operacyjnym i dobrą praktyką inżynierską (ISO 16486-6:2012). Minimalne promienie gięcia rur z PA 12 w zależności od temperatury układania, na podstawie instrukcji instalacji opracowanej przez KRV (Kunststoffrohrverband e.V., 2016), przedstawiono $\mathrm{w}$ tabeli 5.

Tabela 5. Minimalne promienie gięcia w zależności od temperatury układania

Table 5. Minimum bending radius depending on the laying temperature

\begin{tabular}{|c|c|}
\hline Temperatura ukladania & Minimalny promień gięcia $\boldsymbol{R}$ \\
\hline$\left[{ }^{\circ} \mathbf{C}\right]$ & {$[\mathbf{m m}]$} \\
\hline 0 & $50 \times d$ \\
\hline 10 & $35 \times d$ \\
\hline 20 & $20 \times d$ \\
\hline
\end{tabular}

Elastyczność i wytrzymałość rur z PA 12 pozwala na stosowanie techniki zaciskania do zamykania przepływu gazu zarówno w przypadkach awaryjnych, jak i podczas prac eksploatacyjnych. Określenie odporności rur PA 12 na zaciskanie nie jest jednak wymagane obligatoryjnie dla rur poddawanych ocenie zgodności z wymaganiami normy ISO 16486-2:2012. Obowiązek ten spoczywa na producencie rur. W ramach działalności statutowej INiG - PIB w 2018 r. zrealizowano pracę, której wyniki potwierdziły, że rury poddane oddziaływaniu zaciskania w temperaturze $0^{\circ} \mathrm{C}$ uzyskiwały pozytywne wyniki badania wytrzymałości hydrostatycznej przy parametrach badania utrzymywanych jak dla rur niepoddawanych żadnym oddziaływaniom (rys. 2). 


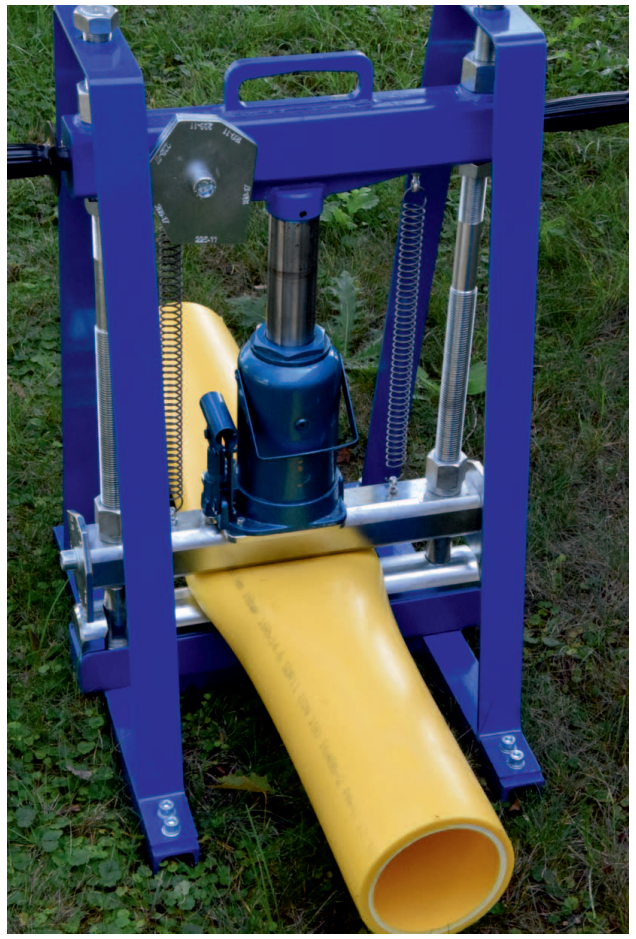

Rys. 2. Zaciśnięta rura z PA 12

Fig. 2. Squeeze-off PA12 pipe

Powinno się jednak mieć na uwadze, że elastyczność rur poliamidowych zmniejsza się w niskich temperaturach i wymagane jest zachowanie większej ostrożności podczas obchodzenia się z nimi zimą (ISO 16486-6:2012). Należy wówczas przestrzegać dodatkowych instrukcji określających sposób postępowania $\mathrm{z}$ rurami w kręgach, gdy temperatura jest niższa niż $0^{\circ} \mathrm{C}$, oraz z rurami w odcinkach prostych, gdy temperatura jest niższa niż $-15^{\circ} \mathrm{C}$.

Niskie temperatury powodują również pewne ograniczenia w łączeniu metodą zgrzewania. Zgrzewanie tworzyw termoplastycznych w temperaturach otoczenia $<5^{\circ} \mathrm{C}$ jest ogólnie uważane za problematyczne (DVS 2207-16:2010) i wynika to nie tyle $\mathrm{z}$ właściwości materiału, co z ograniczonej sprawności zgrzewarek. Do wykonywania połączeń zgrzewanych rur i kształtek z PA 12 metodą doczołową oraz elektrooporową można wykorzystywać te same urządzenia, które stosuje się do zgrzewania systemów z polietylenu, i powinny one spełniać wymagania określone w normach ISO 12176-1:2012 i ISO 12176-2:2008 (rys. 3). Jednym z elementów podlegających ocenie jest układ regulacji temperatury płyty grzewczej, która powinna być utrzymywana w granicach $\pm 7^{\circ} \mathrm{C}$. Badanie to wykonuje się w temperaturze otoczenia $23 \pm 2^{\circ} \mathrm{C}$ i tylko w przypadku wyniku negatywnego, po niezbędnych regulacjach/naprawach, konieczne jest ponowne badanie w temperaturze otoczenia $-10^{\circ} \mathrm{C} \mathrm{i}+40^{\circ} \mathrm{C}$ (Wróblewska, 2017). Badanie w niskiej temperaturze nie jest więc obligatoryjne, dlatego też przed zastosowaniem urządzenia w takich warunkach należy się upewnić, czy jego producent deklaruje taką możliwość.
Zalecaną praktyką przy wykonywaniu połączeń zgrzewanych dla temperatury otoczenia niższej niż $0^{\circ} \mathrm{C}$ jest ustawianie namiotów i nagrzewanie powietrza tak, aby przeznaczone do łączenia elementy miały temperaturę dodatnią, a ich poziom był identyczny.

Dużym problemem podczas łączenia metodą zgrzewania jest również wilgoć. Elementy do zgrzewania należy tak przygotowywać, aby unikać dostania się jej do miejsca połączenia. Poliamidy to materiały o zwiększonej chłonności wody, nawet do $2,8 \%$. Zależy ona jednak od typu poliamidu oraz wprowadzonych dodatków (Plastservice) i w przypadku poliamidu PA 12 przeznaczonego do produkcji rur i kształtek do gazu nie przekracza 0,1\% (ISO 16486-1:2012). Ze względu na tę właściwość zalecane jest stosowanie do oczyszczania powierzchni przeznaczonych do zgrzewania środków zapewniających 100-procentowe odparowanie, np. 99 części etanolu o stopniu czystości 99,8\% i jednej części MEK (keton metylowo-etylowy) (DVS 2207-16:2010). Użycie alkoholu jako środka czyszczącego nie jest zalecane, gdyż ze względu na zawartą w nim wodę będzie prowadziło do obniżenia jakości połączeń.

Uzyskanie wysokiej jakości połączeń zgrzewanych zależy od wielu czynników, a jednym z nich jest temperatura zgrzewania, która powinna uwzględniać temperaturę topnienia materiału, dla poliamidu PA 12 wynoszącą $180^{\circ} \mathrm{C}$ (Gas Technology Institute, 2005). Wykonanie połączenia przy zbyt wysokiej temperaturze może spowodować przegrzanie materiału, a zbyt niska temperatura niedostateczne jego uplastycznienie. Dlatego też zalecane jest wykonywanie połączeń zgrzewanych w zakresie temperatury od $220^{\circ} \mathrm{C}$ do $260^{\circ} \mathrm{C}$ (ISO 16486-6:2012). Drugim bardzo istotnym parametrem podczas wykonywania połączeń zgrzewanych metodą doczołową (rys. 4) jest nacisk jednostkowy na powierzchni łączonych elementów, który powinien wynosić $0,30 \mathrm{~N} / \mathrm{mm}^{2}$ (ISO 16486-5:2012) i jest dwukrotnie większy niż dla PE.

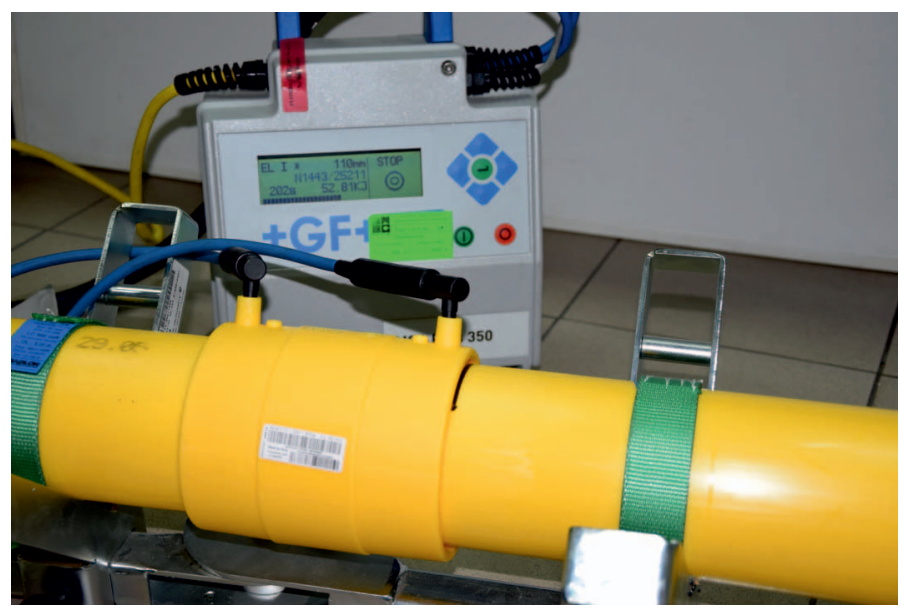

Rys. 3. Proces zgrzewania elektrooporowego kształtki i rur z PA 12

Fig. 3. The process of electrofusion welding of PA12 fitting and pipes 


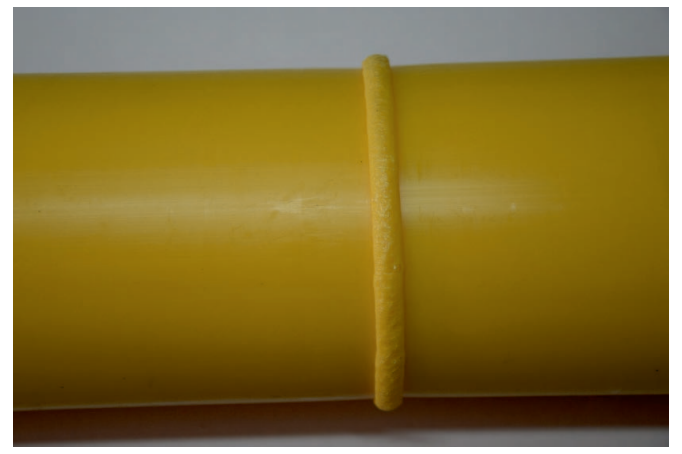

Rys. 4. Zgrzew doczołowy rur PA 12

Fig. 4. Butt fusion weld of PA12 pipes

Kolejną właściwością rur z PA 12, którą należy uwzględnić podczas budowy gazociągów, jest wartość modułu Younga, tj. modułu, od którego zależy sztywność obwodowa rury. To jeden z parametrów, który będzie miał wpływ na przebieg próby szczelności, podczas której ze względu na właściwości lepkosprężyste materiału rurociąg będzie się odkształcał, powodując spadek ciśnienia. Wielkość odkształcenia będzie zależała właśnie między innymi od wartości modułu Younga, który dla rur z PA 12 jest większy niż dla rur z PE.

Podczas realizowanych w INiG - PIB badań w ramach działalności statutowej (Szewczyk, 2018) wykazano, że ze względu na większą wartość modułu Younga dla rur z PA 12 niż dla rur z PE nie jest możliwe wykorzystanie dostępnych metod prowadzenia prób szczelności gazociągów z tworzyw sztucznych o MOP = 1,6 MPa bez modyfikacji ich parametrów.

\section{Podsumowanie}

Jak przedstawiono w artykule, poliamid PA 12 ma wiele cech wspólnych z PE i większość zasad stosowanych przy budowie i eksploatacji gazociągów z polietylenu może zostać przeniesiona na gazociągi z poliamidu, tj.:

- ustalając maksymalne ciśnienie robocze, należy stosować kryterium wytrzymałościowe związane z MRS materiału rury oraz kryterium uwzględniające ciśnienie krytyczne szybkiej propagacji pęknięć;

- dopuszczalne zarysowania powierzchni rur nie powinny być większe niż $10 \%$ grubości ścianki;

- budowa gazociągów technikami alternatywnymi, np. bez podsypki i obsypki piaskowej, jest możliwa po sprawdzeniu dodatkowych właściwości w stosunku do zawartych w normach wyrobu, np. odporności na naciski punktowe;

- maksymalny czas składowania rur narażonych na promieniowanie UV wynosi 1 rok;

- zmiany kierunku gazociągu można realizować dzięki elastyczności rur, stosując minimalne promienie gięcia uzależnione od temperatury, tak jak dla PE;
- zamykanie przepływu gazu można wykonywać, stosując technikę zaciskania rur.

Ze względu na odmienne właściwości poliamidu i polietylenu różnice wystąpią podczas:

- zgrzewania rur metodą doczołową - zgrzewanie z większym naciskiem jednostkowym i przy wyższej temperaturze;

- czyszczenia powierzchni przeznaczonych do zgrzewania - ze względu na możliwą chłonność wody przez poliamid należy stosować środki zapewniające 100-procentowe odparowanie - nie jest zalecane stosowanie alkoholu;

- przeprowadzania prób szczelności - ze względu na większą wartość modułu Younga dostępne metody prowadzenia prób szczelności gazociągów z tworzyw sztucznych o MOP = 1,6 MPa powinny być poddane modyfikacji.

Artykuł powstał na podstawie pracy statutowej pt.: Modyfikacja znormalizowanej metody prowadzenia prób ciśnieniowych celem jej wykorzystania do badania szczelności gazociagów z poliamidu PA-12 - praca INiG - PIB na zlecenie MNiSW; nr zlecenia: 0056/GP/2018, nr archiwalny: DK-4100-0056/2018.

\section{Literatura}

Evonik Resource Efficiency GmbH, 2018. VESTAMID ${ }^{\circledR}$ NRG FOR GAS DISTRIBUTION.

Gas Technology Institute, 2005. Technical Reference on the physi$\mathrm{cal}$, mechanical and chemical properties of polyamide 12 (PA12) for high pressure gas distribution applications. GTI Technical Reference Report April 2004 - December 2005. Prepared by Hitesh Patadia. <https://www.vestamid.com/product/peekindustrial/downloads/gti-technical-reference-summary-en.pdf $>$ (dostęp: 24.04.2019).

Janson L.-E., Molin J. Projektowanie i wykonawstwo sieci zewnętrznych z tworzyw sztucznych. Wavin Metalplast-Buk.

Kunststoffrohrverband e.V. 2016. KRV Installation Instructions A1465, Pressure Pipes, Gas, Water and Sewers Outside of Buildings. <https://www.krv.de/system/files/downloads/pressure_pipes_gas_water_and_sewers_outsite_of_buildings.pdf $>$ (dostęp: 26.04.2019).

Plastem - P. Ciupa i T. Teodorczyk - Spółka Jawna. Poliamid PA. $<$ http://www.plastem.pl/oferta/tworzywa-sztuczne/poliamid-pa/> (dostęp: 26.02.2019).

Plastservice. Tworzywa konstrukcyjne. <http://www.plastservice. net.pl/oferta,2.html> (dostęp: 26.02.2019).

Politechnika Wrocławska. Identyfikacja tworzyw. Polimery Informacje ogólne. <http://www.tworzywa.pwr.wroc.pl/pl/dydaktyka/identyfikacja-tworzyw> (dostęp: 26.02.2019).

Szewczyk P., 2012. Badania odporności na oddziaływania punktowe rur polietylenowych warstwowych układanych $w$ gruncie rodzimym, przeznaczonych do przesyłania gazu. Nafta-Gaz, 9: 611-616.

Szewczyk P., 2018. Ciśnieniowe próby szczelności gazociągów z tworzyw sztucznych o MOP 1,6 MPa. Nafta-Gaz, 5: 386-390. DOI: 10.18668/NG.2018.05.06.

Wróblewska A., 2013. Szybka propagacja pęknięć w sieciach gazowych z rur polietylenowych. Nafta-Gaz, 10: 788-793.

Wróblewska A., 2017. Funkcjonalność zgrzewarek jako jeden z czynników decydujących o jakości połączeń zgrzewanych rur i kształtek z polietylenu. Nafta-Gaz, 12: 953-957. DOI: 10.18668/ NG.2017.12.06. 


\section{Akty prawne i normatywne}

DVGW GW 335-A6(P):2015. Plastic piping systems in gas and water supply; requirements and tests; Part A6: PA-U 160 and PA-U 180 pipes and their joints and jointing.

DVS 2207-16:2010. Welding of thermoplastics - Heated tool welding of pipes and piping parts made of Polyamide 12 .

ISO 12176-1:2012. Plastics pipes and fittings. Equipment for fusion jointing polyethylene systems - Part 1: Butt fusion.

ISO 12176-2:2008. Plastics pipes and fittings. Equipment for fusion jointing polyethylene systems - Part 2: Electrofusion.

ISO 16486-1:2012. Plastics piping systems for the supply of gaseous fuels - Unplasticized polyamide (PA-U) piping systems with fusion jointing and mechanical jointing - Part 1: General.

ISO 16486-2:2012. Plastics piping systems for the supply of gaseous fuels - Unplasticized polyamide (PA-U) piping systems with fusion jointing and mechanical jointing - Part 2: Pipes.

ISO 16486-3:2012. Plastics piping systems for the supply of gaseous fuels - Unplasticized polyamide (PA-U) piping systems with fusion jointing and mechanical jointing - Part 3: Fittings.

ISO 16486-5:2012. Plastics piping systems for the supply of gaseous fuels - Unplasticized polyamide (PA-U) piping systems with fusion jointing and mechanical jointing - Part 5: Fitness for purpose of the system.
ISO 16486-6:2012. Plastics piping systems for the supply of gaseous fuels - Unplasticized polyamide (PA-U) piping systems with fusion jointing and mechanical jointing - Part 6: Code of practice for design, handling and installation.

PN-EN ISO 13479:2013. Rury z poliolefin do przesyłania płynów Oznaczanie odporności na propagację pęknięć - Metoda badania powolnego wzrostu pęknięć $\mathrm{w}$ rurach $\mathrm{z}$ karbem.

Rozporządzenie Ministra Gospodarki z dnia 26 kwietnia 2013 r. w sprawie warunków technicznych, jakim powinny odpowiadać sieci gazowe i ich usytuowanie (Dz.U. z 2013 r. poz. 640).

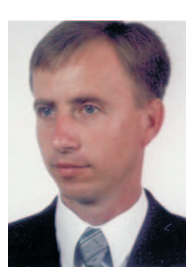

Mgr inż. Piotr SZEWCZYK

Główny specjalista inżynieryjno-techniczny; kierownik Zakładu Przesyłania i Dystrybucji Gazu Instytut Nafty i Gazu - Państwowy Instytut Badawczy ul. Lubicz 25 A

31-503 Kraków

E-mail: piotr.szewczyk@inig.pl

OFERTA BADAWCZA ZAKŁADU PRZESYKANIA I DYSTRYBUCJI GAZU

badania rur, ksztattek i armatury z tworzyw sztucznych stosowanych do budowy sieci gazowych, wodociągowych oraz do ciśnieniowej kanalizacji deszczowej i sanitarnej;

badania systemów przewodów rurowych do instalacii wody cieptej i zimnej wewnątrz budynków np. PE-X/Al/PE-X, PP, PB, PE-X: badania armatury metalowej do sieci i instalacji gazowych oraz wodociągowych;

badania armatury do instalacii centralnego ogrzewania i solarnych;

badania armatury sanitarnej, np. baterii mechanicznych, termostatycznych; mieszających, zaworów wypływowych, natrysków i przewodów natryskowych;

badania reduktorów średniego ciśnienia;

badania powtok ochronnych z tworzyw sztucznych na rurach i armaturze stalowej:

ocena stopnia zagrożenia korozyjnego gazociągów stalowych oraz ocena stanu technicznego izolacji gazociagów stalowych metodami bezwykopowymi

analiza zagrożeń korozyjnych na tłoczniach i magazynach gazu oraz instalacji związanych z ropociągami, wodociągami i podziemnymi zbiornikami;

ocena efektywności metod rekonstrukcii sieci dystrybucyjnych gazu;

badania z zakresu wspótpracy ośrodka gruntowego z siecią gazową na terenach górniczych;

opiniowanie projektów przepisów oraz norm związanych z budową i użytkowaniem sieci gazowych;

prowadzenie specjalistycznych szkoleń z zakresu budowy sieci gazowych z polietylenu z zastosowaniem technologii zgrzewania doczotowego i elektrooporowego:

szkolenie i kwalifikacja personelu zgrzewającego rury i ksztattki z PE wg PN-EN 13067 w INiG-PIB jako Ośrodku Szkoleniowym i Egzaminacyinym uznanym przez UDT-CERT;

ocena jakości połączeń zgrzewanych rur i ksztattek z PE na potrzeby kwalifikacji personelu zgrzewającego wg normy PN-EN 13067 w Laboratorium Tworzyw Sztucznych uznanym przez UDT;

wspomaganie przemysłu we wdrażaniu nowych rozwiązań technicznych oraz opracowywanie ekspertyz i analiz.

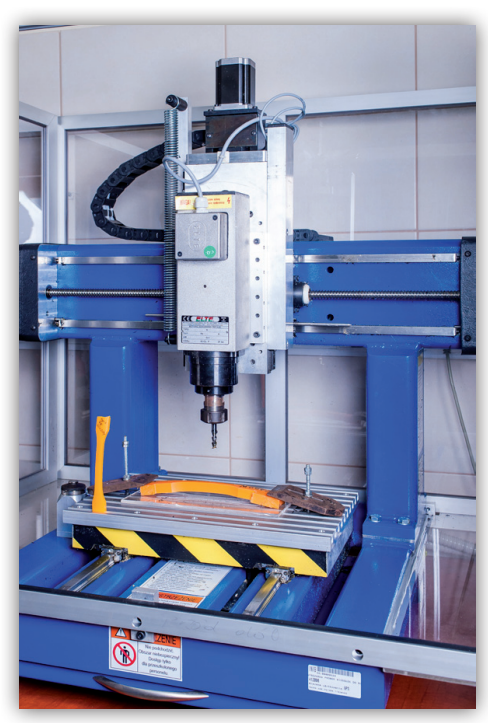

Kierownik: mgr inż. Piotr Szewczyk Adres: ul. Bagrowa 1, 30-733 Kraków 